\title{
Prevalence of Anterior Tooth Fracture due to Trauma
}

\author{
${ }^{1}$ Mithra N Hegde, ${ }^{2}$ Shaheen Abootty, ${ }^{3}$ Shruthi Attavar
}

\begin{abstract}
Aim: To evaluate the prevalence of anterior tooth fracture due to trauma in 2000 patients randomly from the population of south Canara district.
\end{abstract}

Materials and methods: The present study was conducted on 2000 patients attending the Department of Conservative Dentistry and Endodontics, AB Shetty Dental College, Mangalore, and rural satellite centers of Nitte University. Each patient was examined for anterior to oth fracture due to trauma under dental chair in a good illumination of light using sterilized mouth mirror, explorer, tweezer and teeth are isolated by cotton roles. The patient who had anterior tooth fracture were questioned with a standard questionnaire from oral health survey WHO format 2013 , to find its relation associated to age, gender, location, occupation, etiology, type of fracture and its relation to molar.

Results: According to the present study, prevalence of anterior tooth fracture due to trauma in south Canara population was low and found to be $18.8 \%$ with increase in prevalence in males $(56.2 \%)$ between the age group of 36 and 45 years (33.2\%), common etiological factor seen was falls $(44.7 \%)$. The most common type of fracture was enamel-dentine fracture $(44.7 \%)$ with class 1 molar relation (55.6\%).

Conclusion: The prevalence of anterior tooth fracture due to trauma was most commonly seen in males with increased prevalence in age group between 36 and 45 years, common etiological factor being falls, type of fracture most commonly seen are cases with enamel-dentine fracture with class 1 molar relation.

Keywords: Anterior tooth, Falls, Fracture, Trauma.

How to cite this article: Hegde MN, Abootty S, Attavar S. Prevalence of Anterior Tooth Fracture due to Trauma. World J Dent 2015;6(2):77-81.

\section{Source of support: Nil}

Conflict of interest: None

\section{INTRODUCTION}

A dental practitioner frequently encounters management of traumatic injuries to the teeth and its supporting tissue during the course of his dental practice. ${ }^{1}$ Traumatic dental injury (TDI) has been a great public dental health

\footnotetext{
${ }^{1}$ Senior Professor and Head, ${ }^{2}$ Postgraduate Student

${ }^{3}$ Senior Lecturer

${ }^{1-3}$ Department of Conservative Dentistry and Endodontics AB S hetty Memorial Institute of Dental Sciences, Nitte University Deralakatte, Mangalore, Karnataka, India
}

Corresponding Author: Mithra N Hegde, Senior Professor and Head, Department of Conservative Dentistry and Endodontics AB Shetty Memorial Institute of Dental Sciences, Nitte University Deralakatte, Mangalore-575018, Karnataka, India, Phone: +91 98452 84411, e-mail: drhegdedentist@ gmail.com concern due to various reasons, some of which being its occurrence at a young age, the cost and the duration of the treatment, which may even continue lifelong. The number of traumatic dental injuries, resulting from facial trauma has shown a marked increase since last 30 years, it now includes a broad spectrum of variables like oral and environmental factors and human behavior. Fracture, displacement or loss of teeth that are an outcome of facial trauma can have a significant negative functional and esthetics effect on the individual. ${ }^{2}$

Traumatic dental injuries are caused due to an external impact on a tooth and its surrounding tissues. ${ }^{1}$ The impact may either be direct or indirect. The outcome of a TDI may be damage to dental as well as peri-radicular structures. There is exhibition of various types of dental injuries starting from minor enamel fractures to complicated fractures of crown and/or root and even extraction. ${ }^{2}$

Traumatic dental injuries can occur during any age group, but prevale more frequently in teenagers. ${ }^{3}$ It may be due to various causes like falls, accidents or outcome of violence. Traumatic dental injuries have also shown to occur in males and with single tooth involvement being the most affected are class 2 fracture. It is a genuine dental emergency which require immediate assessment and management specially in young ages (5-7 years), when many present teeth continues to develop. ${ }^{4}$ Dental professionals are quite aware about the risks of traumatic dental injuries but they are not able to disseminate the same to general public and prevent its occurring, also several epidemiologic studies have referred it as a serious dental health problem. ${ }^{3}$

Hence, the aim of the present study is to evaluate the prevalence of anterior tooth fracture due to trauma.

\section{MATERIALS AND METHODS}

After obtaining institutional ethical clearance, the study was conducted in month of June to July 2014, on randomly selected 2000 patients from the outpatient department of conservative dentistry and endodontics and its five different rural centers.

\section{Sample Selection Criteria}

Urban group was the patients reporting to Department of Conservative Dentistry and Endodontics, AB Shetty Memorial Institute of Dental Sciences, Deralakatte, Mangalore. Rural group was the patients reporting to five rural centers in Bailoor, Firangipet, Hejimadikody, 
Mundkoor and Nitte. Patients, who were selected randomly, were segregated in six groups based on age between 15 and 66 years.

\section{Exclusion Criteria}

- Patient undergoing orthodontic treatment.

- Patients with recent maxillofacial trauma.

- Patients with limited mouth opening.

\section{Inclusion Criteria}

- Patient above the age group of 15 years.

- Patient who are not physically or mentally challenged. All the patients were informed about the nature of the survey and its objectives and were ensured, complete confidentiality of their information. A verbal informed consent was taken. A standardized questionnaire was prepared according to WHO health assessment form 2013 which was filled by the examiner.

\section{Clinical Examination}

Each patient was examined for anterior tooth fracture under dental chair in a good illumination of light using sterilized mouth mirror, explorer and tweezer. The patients who had fractured anterior teeth due to trauma were questioned with a standard questionnaire to find its relation associated with age, gender, location, occupation, etiology, anterior tooth fracture classified according to WHO classification, molar relationship according to Angle's classification.

\section{Scoring Criteria: WHO Scoring Criteria}

Teeth affected by dental trauma are coded as follows:

- 0 -No sign of injury

- 1-Treated injury

- 2-Enamel fracture only (plate 47)

- 3-Enamel and dentine fracture (plate 48)

- 4-Pulp involvement (plate 49)

- 5-Missing tooth due to trauma (plate 50)

- 6-Other damage

- 9-Excluded tooth

All completed questionnaires were analyzed and the data were transferred on the Microsoft Office Excel sheet and subjected to SPSS version 16 to statistically analyze using Pearson's Chi-square test. $\mathrm{p}<0.05$ was considered to be statistically significant.

\section{RESULTS}

\section{Prevalence of Anterior Tooth Fracture due to Trauma}

The sample size of this study included 2000 patients. Out of 2000 patients, $365(18.8 \%)$ cases had due to anterior tooth fracture due to trauma.

\section{Prevalence of Anterior Tooth Fracture due to Trauma with Respect to Age}

Out of 365 cases with anterior tooth fracture due to trauma, $33.2 \%$ of cases were noticed in the age group of 36 to 45 years of age and $25.8 \%$ of cases were seen in the age group of 25 to 35 years of age (Table 1 ).

\section{Prevalence of Anterior Tooth Fracture due to Trauma with Respect to Gender}

Out of 365 cases with anterior tooth fracture due to trauma, $56.2 \%$ cases affected are males and $43.8 \%$ of cases affected were females (Table 2).

\section{Prevalence of Anterior Tooth Fracture due to Trauma with Respect to Occupation}

Out of 365 patients with anterior tooth fracture due to trauma, $38.4 \%$ of the cases were seen among workers, $20.6 \%$ of cases were seen among housewives (Table 3 ).

\section{Prevalence of Anterior Tooth Fracture with Respect to Location}

Out of 365 cases with anterior tooth fracture due to trauma, $45.2 \%$ cases were seen in rural centers and $43.2 \%$ were seen in urban areas (Table 4).

Table 1: Prevalence of anterior tooth fracture due to trauma with respect to age

\begin{tabular}{|c|c|c|c|c|c|}
\hline \multirow{4}{*}{\multicolumn{2}{|c|}{ Age $\quad 15-25$}} & & & Fracture & Total \\
\hline & & \multicolumn{2}{|l|}{ Count } & 28 & 126 \\
\hline & & \multicolumn{2}{|c|}{ Percentage within age } & $22.2 \%$ & $100.0 \%$ \\
\hline & & \multicolumn{2}{|c|}{ Percentage within fracture } & $7.7 \%$ & $6.3 \%$ \\
\hline & $26-35$ & \multicolumn{2}{|c|}{ Count } & 92 & 514 \\
\hline & & \multicolumn{2}{|c|}{ Percentage within age } & $17.9 \%$ & $100.0 \%$ \\
\hline & & \multicolumn{2}{|c|}{ Percentage within fracture } & $25.2 \%$ & $25.7 \%$ \\
\hline & $36-45$ & \multicolumn{2}{|c|}{ Count } & 121 & 640 \\
\hline & & \multicolumn{2}{|c|}{ Percentage within age } & $18.9 \%$ & $100.0 \%$ \\
\hline & & \multicolumn{2}{|c|}{ Percentage within fracture } & $33.2 \%$ & $32.0 \%$ \\
\hline & $46-55$ & \multicolumn{2}{|c|}{ Count } & 64 & 412 \\
\hline & & \multicolumn{2}{|c|}{ Percentage within age } & $15.5 \%$ & $100.0 \%$ \\
\hline & & \multicolumn{2}{|c|}{ Percentage within fracture } & $17.5 \%$ & $20.6 \%$ \\
\hline & $56-65$ & \multicolumn{2}{|c|}{ Count } & 50 & 254 \\
\hline & & \multicolumn{2}{|c|}{ Percentage within age } & $19.7 \%$ & $100.0 \%$ \\
\hline & & \multicolumn{2}{|c|}{ Percentage within fracture } & $13.7 \%$ & $12.7 \%$ \\
\hline & $>66$ & \multicolumn{2}{|c|}{ Count } & 10 & 54 \\
\hline & & \multicolumn{2}{|c|}{ Percentage within age } & $18.5 \%$ & $100.0 \%$ \\
\hline & & \multicolumn{2}{|c|}{ Percentage within fracture } & $2.7 \%$ & $2.7 \%$ \\
\hline \multirow{3}{*}{\multicolumn{2}{|c|}{ Total }} & \multicolumn{2}{|c|}{ Count } & 365 & 2000 \\
\hline & & \multicolumn{2}{|c|}{ Percentage within age } & $18.2 \%$ & $100.0 \%$ \\
\hline & & \multicolumn{2}{|c|}{ Percentage within fracture } & $100.0 \%$ & $100.0 \%$ \\
\hline \multicolumn{6}{|c|}{ Chi-square test } \\
\hline & & & Value $\quad d f$ & \multicolumn{2}{|c|}{$p$-value } \\
\hline \multicolumn{3}{|c|}{ Pearson's Chi-square } & $3.950^{\mathrm{a}}$ & \multicolumn{2}{|c|}{0.557} \\
\hline \multicolumn{6}{|c|}{ No. of valid cases 2000} \\
\hline
\end{tabular}

${ }^{a} 0$ cells $(0.0 \%)$ have expected count less than 5 . The minimum expected count is 9.86 
Prevalence of Anterior Tooth F racture due to Trauma

Table 2: Prevalence of anterior tooth fracture due to trauma with respect to gender

\begin{tabular}{|c|c|c|c|c|}
\hline & & & Fracture & Total \\
\hline \multirow[t]{6}{*}{ Gender } & \multirow[t]{3}{*}{ Male } & Count & 205 & 1100 \\
\hline & & $\begin{array}{l}\text { Percentage within } \\
\text { gender }\end{array}$ & $18.6 \%$ & $100.0 \%$ \\
\hline & & $\begin{array}{l}\text { Percentage within } \\
\text { fracture }\end{array}$ & $56.2 \%$ & $55.0 \%$ \\
\hline & \multirow[t]{3}{*}{ Female } & Count & 160 & 900 \\
\hline & & $\begin{array}{l}\text { Percentage within } \\
\text { gender }\end{array}$ & $17.8 \%$ & $100.0 \%$ \\
\hline & & $\begin{array}{l}\text { Percentage within } \\
\text { fracture }\end{array}$ & $43.8 \%$ & $45.0 \%$ \\
\hline \multirow[t]{3}{*}{ Total } & & Count & 365 & 2000 \\
\hline & & $\begin{array}{l}\text { Percentage within } \\
\text { gender }\end{array}$ & $18.2 \%$ & $100.0 \%$ \\
\hline & & $\begin{array}{l}\text { Percentage within } \\
\text { fracture }\end{array}$ & $100.0 \%$ & $100.0 \%$ \\
\hline
\end{tabular}

\begin{tabular}{llll}
\hline \multicolumn{4}{c}{ Chi-square test } \\
\hline & Value & df & p-value \\
\hline Pearson's Chi-square & $0.245^{\mathrm{a}}$ & 1 & 0.621 \\
No. of valid cases & 2000 & & \\
\hline a cells $(0.0 \%)$ have expected count less than & 5. The minimum \\
expected count is 164.25
\end{tabular}

Table 3: Prevalence of anterior tooth fracture due to trauma with respect to occupation

\begin{tabular}{|c|c|c|c|c|}
\hline & & & Fracture & Total \\
\hline \multirow{15}{*}{$\begin{array}{l}\text { Occu- } \\
\text { pation }\end{array}$} & \multirow[t]{3}{*}{ Laborer } & Count & 46 & 221 \\
\hline & & $\begin{array}{l}\text { Percentage within } \\
\text { occupation }\end{array}$ & $20.8 \%$ & $100.0 \%$ \\
\hline & & $\begin{array}{l}\text { Percentage within } \\
\text { fracture }\end{array}$ & $12.6 \%$ & $11.1 \%$ \\
\hline & \multirow[t]{3}{*}{ Housewife } & Count & 70 & 407 \\
\hline & & $\begin{array}{l}\text { Percentage within } \\
\text { occupation }\end{array}$ & $17.2 \%$ & $100.0 \%$ \\
\hline & & $\begin{array}{l}\text { Percentage within } \\
\text { fracture }\end{array}$ & $19.2 \%$ & $20.4 \%$ \\
\hline & \multirow[t]{3}{*}{ Student } & Count & 22 & 117 \\
\hline & & $\begin{array}{l}\text { Percentage within } \\
\text { occupation }\end{array}$ & $18.8 \%$ & $100.0 \%$ \\
\hline & & $\begin{array}{l}\text { Percentage within } \\
\text { fracture }\end{array}$ & $6.0 \%$ & $5.9 \%$ \\
\hline & \multirow[t]{3}{*}{ Worker } & Count & 140 & 813 \\
\hline & & $\begin{array}{l}\text { Percentage within } \\
\text { occupation }\end{array}$ & $17.2 \%$ & $100.0 \%$ \\
\hline & & $\begin{array}{l}\text { Percentage within } \\
\text { fracture }\end{array}$ & $38.4 \%$ & $40.7 \%$ \\
\hline & \multirow[t]{3}{*}{ Business } & Count & 87 & 441 \\
\hline & & $\begin{array}{l}\text { Percentage within } \\
\text { occupation }\end{array}$ & $19.7 \%$ & $100.0 \%$ \\
\hline & & $\begin{array}{l}\text { Percentage within } \\
\text { fracture }\end{array}$ & $23.8 \%$ & $22.1 \%$ \\
\hline \multirow[t]{3}{*}{ Total } & & Count & 365 & 1999 \\
\hline & & $\begin{array}{l}\text { Percentage within } \\
\text { occupation }\end{array}$ & $18.3 \%$ & $100.0 \%$ \\
\hline & & $\begin{array}{l}\text { Percentage within } \\
\text { fracture }\end{array}$ & $100.0 \%$ & $100.0 \%$ \\
\hline
\end{tabular}

\begin{tabular}{llll}
\hline \multicolumn{4}{c}{ Chi-square test } \\
\hline Value & df & p-value \\
\hline Pearson's Chi-square & $2.522^{\mathrm{a}}$ & 4 & 0.641 \\
No. of valid cases & 1999 & & \\
\hline${ }^{\mathrm{a}} 0$ cells $(0.0 \%)$ have expected count less than 5. The minimum \\
expected count is 21.36
\end{tabular}

Table 4: Prevalence of anterior tooth fracture due to trauma with respect to location

\begin{tabular}{|c|c|c|c|c|}
\hline & & & Fracture & Total \\
\hline \multirow[t]{9}{*}{ Location } & \multirow[t]{3}{*}{ Urban } & Count & 160 & 957 \\
\hline & & $\begin{array}{l}\text { Percentage within } \\
\text { location }\end{array}$ & $16.7 \%$ & $100.0 \%$ \\
\hline & & $\begin{array}{l}\text { Percentage within } \\
\text { fracture }\end{array}$ & $43.8 \%$ & $47.8 \%$ \\
\hline & \multirow[t]{3}{*}{ Rural } & Count & 165 & 843 \\
\hline & & $\begin{array}{l}\text { Percentage within } \\
\text { location }\end{array}$ & $19.6 \%$ & $100.0 \%$ \\
\hline & & $\begin{array}{l}\text { Percentage within } \\
\text { fracture }\end{array}$ & $45.2 \%$ & $42.2 \%$ \\
\hline & \multirow{3}{*}{$\begin{array}{l}\text { Semi- } \\
\text { urban }\end{array}$} & Count & 40 & 200 \\
\hline & & $\begin{array}{l}\text { Percentage within } \\
\text { location }\end{array}$ & $20.0 \%$ & $100.0 \%$ \\
\hline & & $\begin{array}{l}\text { Percentage within } \\
\text { fracture }\end{array}$ & $11.0 \%$ & $10.0 \%$ \\
\hline \multirow[t]{3}{*}{ Total } & & Count & 365 & 2000 \\
\hline & & $\begin{array}{l}\text { Percentage within } \\
\text { location }\end{array}$ & $18.2 \%$ & $100.0 \%$ \\
\hline & & $\begin{array}{l}\text { Percentage within } \\
\text { fracture }\end{array}$ & $100.0 \%$ & $100.0 \%$ \\
\hline
\end{tabular}

\begin{tabular}{llll}
\hline \multicolumn{4}{c}{ Chi-square test } \\
\hline & Value & df & p-value \\
\hline Pearson's Chi-square & $2.903^{\text {a }}$ & 2 & 0.234 \\
No. of valid cases & 2000 & & \\
\hline $\begin{array}{l}\text { a } 0 \text { cells }(0.0 \%) \text { have expected count less than 5. The minimum } \\
\text { expected count is 36.50 }\end{array}$
\end{tabular}

\section{Prevalence of Anterior Tooth Fracture due to Trauma with Respect to Etiology of Trauma}

Out of 365 patients with anterior tooth fracture due to trauma, $44.7 \%$ were because of falls and rest of the $55.4 \%$ of patients had anterior tooth fracture because of violence, sports and traffic accidents with slight variation in frequency and percentage (Table 5 and Graph 1).

\section{Prevalence of Anterior Tooth Fracture due to Trauma with Respect to Type of Tooth Fracture}

Out of 365 cases with anterior tooth fracture due to trauma, $44.7 \%$ of teeth showed WHO score 3, i.e. enamel and dentine fracture, followed by WHO score 2 was seen in $33.6 \%$ of cases and rest $22 \%$ cases included WHO score 4 and 6 (Table 6 and Graph 2).

Table 5: Prevalence of anterior tooth fracture due to trauma with respect to etiology

\begin{tabular}{llrl}
\hline & & Frequency & $\begin{array}{l}\text { Valid } \\
\text { percentage }\end{array}$ \\
\hline Valid & Fall & 163 & 44.7 \\
& Automobile accident & 122 & 33.4 \\
& Sports accident & 40 & 11.0 \\
& Violence & 40 & 11.0 \\
& Total & 365 & 100.0 \\
Missing & 999 & 1635 & \\
\hline Total & & 2000 & \\
\hline
\end{tabular}




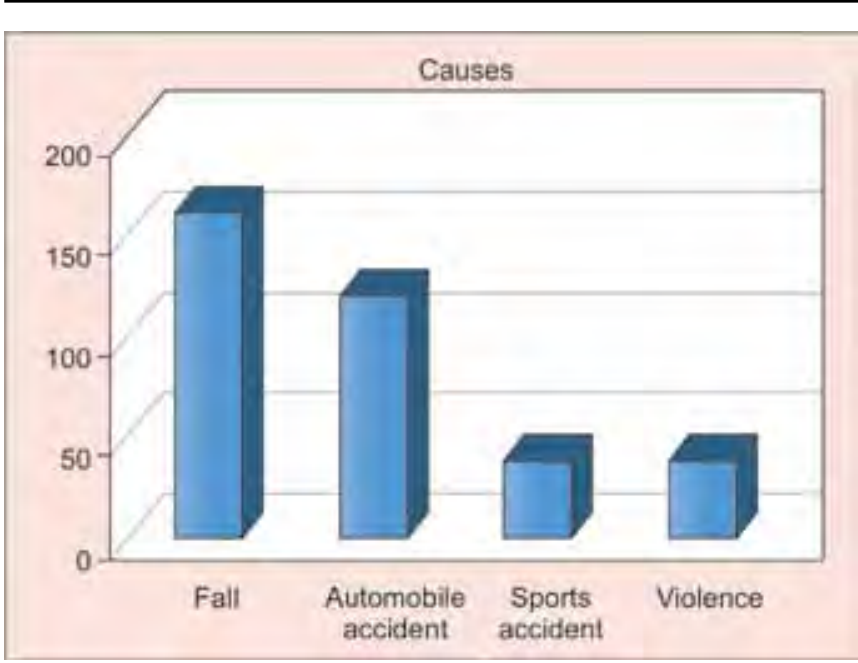

Graph 1: Prevalence of anterior tooth fracture due to trauma with respect to etiology

Table 6: Prevalence of anterior tooth fracture due to trauma with respect to type of tooth fracture

\begin{tabular}{llll}
\hline & WHO scores & Frequency & Valid percentage \\
\hline Valid & Score 2 & 122 & 33.4 \\
& Score 3 & 163 & 44.7 \\
& Score 4 & 40 & 11.0 \\
& Score 6 & 40 & 11.0 \\
& Total & 365 & 100.0 \\
Missing & 999 & 1635 & \\
\hline Total & & 2000 & \\
\hline
\end{tabular}

\begin{tabular}{|c|c|c|}
\hline & \\
\hline
\end{tabular}

Graph 2: Prevalence of anterior tooth fracture due to trauma with respect to type of tooth fracture

\section{Prevalence of Anterior Tooth Fracture due to Trauma with Respect to Molar Relationship}

Out of 365 patients with anterior tooth fracture due to trauma, $55.6 \%$ cases were seen with class 1 molar relation and $44.4 \%$ of cases were seen with class 2 molar relation (Table 7 and Graph 3).

\section{DISCUSSION}

In the present study, it was observed that the overall prevalence of anterior tooth fracture due to trauma
Table 7: Prevalence of anterior tooth fracture due to trauma with respect to molar relation

\begin{tabular}{llll}
\hline & & Frequency & Valid percentage \\
\hline Valid & Class 1 & 203 & 55.6 \\
& Class 2 & 162 & 44.4 \\
& Total & 365 & 100.0 \\
Missing & 999 & 1635 & \\
\hline Total & & 2000 & \\
\hline
\end{tabular}

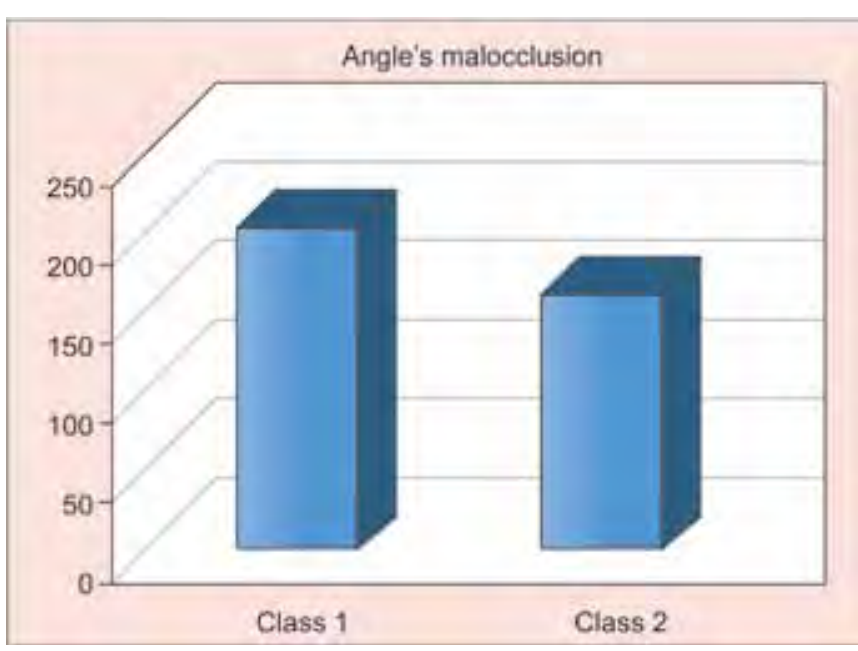

Graph 3: Prevalence of anterior tooth fracture due to trauma with respect to molar relation

was $18.8 \%$ in 2000 patients of south Indian population. In a study conducted by Hegde et al in the same geographical location during the year 2010 to 2011, the overall prevalence was about $11.5 \%$, which shows an increase in the prevalence of anterior teeth fracture due to trauma. Maximum prevalence of fracture of anterior teeth was seen in the age group of 36 to 45 years (33.2\%) followed by the age groups 25 to 35 years (25.2\%) which was not statistically significant $(p>0.001)$ (Table 1$)$. The increase in prevalence is due to their involvement in greater risks of road traffic accidents, falls and general tendancy in taking greater risks. Studies done by Hegde et $\mathrm{al}^{1}$ shows the maximum prevalence of anterior tooth fracture due to trauma in the age group of 15 to 30 years of age, i.e. $53.9 \%$. Similar studies done by Kovács et $\mathrm{al}^{4}{ }^{4}$ Lam et $\mathrm{al}^{5}$ show children and adolescents are the common age group seen in the prevalence of anterior tooth fracture due to trauma.

A study done by Hecova et al concluded that Males are involved in accidental injuries more often than female. Similarly, the prevalence of anterior teeth fracture with respect to gender was found to be males (56.2\%) greater than females $(43.8 \%)$. However, it was not statistically significant ( $p>0.001$ ) (Table 2). Similar result was found in a different geographical location by Glendor, ${ }^{2}$ Caldas et $\mathrm{al}_{1}{ }^{6}$ Andrade et al, ${ }^{7}$ Levin et al, ${ }^{8}$ Hecova et $\mathrm{al}_{1}{ }^{9}$ Lam et $\mathrm{al}^{5}{ }^{5} \mathrm{Zuhal}$ et $\mathrm{al}^{10}$ in their study males showed higher prevalence of anterior tooth fracture due to trauma that could be attributed to occupational hazards, sports injuries, violence, road traffic injuries. 
Studies show that $38.4 \%$ cases were seen among workers and 20.6\% were seen among housewives (Table 3). On comparing the society in which they live, rural population showed higher prevalence of anterior tooth fracture than semiurban, i.e. $45.2 \%$, but it is not statistically significant $(\mathrm{p}>0.001)$ (Table 4).

Anterior tooth fracture due to trauma can prevail due to variety of etiologic factors, fall being the most common one (44.7\%) (Table 5 and Graph 1). Similar findings were observed by Hegde et $\mathrm{al}_{1}{ }^{1}$ Caldas et $\mathrm{al}_{1}{ }^{6}$ Levin et al, ${ }^{8}$ Hecova et al, ${ }^{9}$ Lam et al ${ }^{5} \mathrm{Zuhal}$ et $\mathrm{al}^{10}$ show that the most common etiologic reasons are falls, automobile, bicycle accidents, collisions and sporting activities. Hecova et $\mathrm{al}^{9}$ and Comfort et al ${ }^{11}$ automobile accidents $(33.4 \%)$, sports accidents $(11 \%)$, violence $(11 \%)$ are the rest of the etiologic factors that contributes for anterior tooth fracture due to trauma looking into the type of fracture of the anterior tooth due to trauma, WHO score $3(44.7 \%)$ being the most common one seen in this study (Table 6 and Graph2). Similar findings were observed by Katharina et al, ${ }^{12}$ Hecova et al, ${ }^{9}$ Kovács et al. ${ }^{4}$ Elli's class 1 (33.6\%) being the second most common and the rest $22 \%$ cases included Elli's class 3, 4 and 7 fracture. Whereas studies done by Caldas et $\mathrm{al}^{6}$ and Comfort et al. ${ }^{11}$ The commonest type of injury was enamel fracture alone $(9.9 \%)$, followed by enamel-dentin fracture (4.8\%). Majority of the accidents occurred at home showed that Elli's class 1 was most common. Individuals with Elli's class 1 fracture might not undergo treatment as they don't have any complaints or they won't realize the fracture. This may be due to the fact that individuals do not give importance to their dental injuries as they might not have any pain and esthetic problems.

Taking molar relationship into consideration, prevalence of anterior tooth fracture due to trauma occurred most frequently among patients with class 1 molar relationship (55.6\%) and rest being class 2 molar relationship (44.4\%). This observation was similar with findings of the study by Hegde et $\mathrm{al}^{1}$ (Table 7 and Graph 3).

\section{CONCLUSION}

Traumatic dental injury is a public dental health problem and dental professionals must press for legislation and educational campaigns to prevent dental injuries as well as to provide the necessary information to help policymakers create an appropriate and safe environment. Fall was the most important cause of teeth fracture that are more seen in males with an increased incidence in 36 to 45 years of age. Among the type of fractures seen, enamel-dentin fracture was the most common one with class 1 molar relationship having anterior tooth fracture due to trauma.

\section{REFERENCES}

1. Hegde MN, Shabin S. Incidence of permanent anterior tooth fracture due to trauma in south Indian population: Ind J Dental Traumatol 2013;4(4):120-124.

2. Glendor U. Epidemology of traumatic dental injuries-a 12 year review of the literature. Dental Traumatol 2008;24(6): 603-611.

3. Marcenes W, Al beiruti, Tayfour D, Issa S. Epidemiology of traumatic injuries to the permanent incisors of 9-12 year old school children in Damascus, Syria. Dental Traumatol 1999; 15(3):117-123.

4. Kovács M, Pãcurar M, Petcu B, Bukhari C. Prevalence of traumatic dental injuries in children who attended two dental clinics in târgu mure between 2003 and 2011. Dental Traumatol 2012;11(3):116-112.

5. Lam R, Lloyd C, Lloyd C, Kruger E, Tennant M. Dental trauma in an Australian rural center. Dental Traumatol 2008;24(6): 663-670.

6. Caldas, Burgos MEA. A retrospective study of traumatic dental injuries in a Brazilian dental trauma clinic. Dental Traumatol 2001;17:250-253.

7. Andrade RA, Scabeli PL, Evans, Almeidda ALS, dasilva JJR. Prevalence of dental trauma in Pan American Games athletes. Dental Traumatol 2010;26:248-253.

8. Levin L, Lin S, Goldman S, Peleg K. Relationship between socioeconomic position and general maxillofacial and dental Trauma: a national trauma register study. Dental Traumatol 2010;26:342-345.

9. Hecova H, Kounakis VT, Merglova V, Netolicky J. A retrospective study of 889 injure permanent teeth. Dental Traumatol 2010;26(4):466-475.

10. Zuhal K. Dent-traumatic injuries of the permanent incisors in children in southern Turkey: a retrospective study. Dental Traumatol 2005 Feb;21(1):20-25.

11. Comfort A, Adekoya S, Olufemi A, Wakeel O, Adeleke O, Vincent I. Prevalence and causes of fractured permanent incisors in 12-year-old suburban Nigerian school children. Dental Traumatol 2009;25(3):314-317.

12. Katharina B, Claudia N, Reinhard H, Jan K. Traumatic dental injuries at a German University clinic 2004-2008. Dental Traumatol 2013;29(2):127-133. 